\title{
SHORT WAVE DIATHERMY DAN CORE STABILITY EXERCISE TERHADAP PENINGKATAN KEMAMPUAN FUNGSIONAL PADA PASIEN NYERI PUNGGUNG BAWAH MIOGENIK
}

\author{
Indah Pramita, Antonius Tri Wahyudi \\ Program Studi Fisioterapi Universitas Dhyana Pura, Badung, Bali, Indonesia \\ Email : kd.pramita@gmail.com
}

\begin{abstract}
ABSTRAK
Nyeri Punggung Bawah banyak dijumpai di masyarakat dan merupakan salah satu penyebab kesakitan dan kecacatan. Nyeri punggung bawah mengakibatkan penderita mengalami kesulitan beraktifitas dan melakukan pekerjaan sehari-hari. Latihan core muscle sangat penting bagi penderita nyeri pungung bawah, karena dengan adanya otot core yang kuat akan memungkinkan kerja yang optimal dari tulang belakang dan postur tubuh akan tetap terjaga. Penelitian ini dilakukan dengan tujuan untuk melihat dan membuktikan pengaruh pemberian Short Wave Diathermy dan Core Stability Exercise terhadap peningkatan aktivitas fungsional pada pasien nyeri punggung bawah miogenik. Rancangan penelitian ini bersifat pre eksperimental dengan rancangan pretest and posttest design. Penelitian ini dilaksanakan di klinik swasta di denpasar. Dalam penelitian ini diberikan perlakukan 3x seminggu selama 2 minggu. Hasil uji statistik didapatkan, terjadi penurunan skor $O D I$ dengan nilai $\mathrm{p}=0,001$ dengan nilai selisih rerata $O D I$ sebesar $28,86 \%$. Dari hasil penelitian ini dapat disimpulkan bahwa SWD dan Core Stability Exercise dapat meningkatkan aktivitas fungsional pasien nyeri punggung bawah miogenik.
\end{abstract}

Kata kunci : core stability exercise, $S W D$, nyeri punggung bawah miogenik.

\begin{abstract}
Low back pain is common in the community and is one of the causes of illness and disability. Low back pain causes the patient to experience difficulty in doing activities and daily work. Exercise core muscle is very important for patient with low back pain, because with a strong core muscle will allow optimal work of the spine and posture will remain intact. This study was conducted with the aim to see and prove the effect of Short Wave Diathermy and Core Stability Exercise on the increase of functional activity in patients with low back myogenic. The design of this study is experimental with pre-test and post-test design. The study was conducted at a clinic in denpasar. In this study treated 3 times a week for 2 weeks.The results of statistical test was obtained, occur of decreasing in ODI $p=0.001$ and the difference mean value ODI as $28,86 \%$. From the results of the research can be concluded that the core stability exercises increase the functional activity in patients with myogenic low back pain. The study is expected to be beneficial in patients with myogenic low back pain to improving functional activity.
\end{abstract}

Keywords: core stability exercise, SWD, myogenic low back pain.

\section{PENDAHULUAN}

Nyeri punggung bawah (NPB) adalah gangguan yang ditandai dengan rasa nyeri di daerah punggung bagian bawah (Tiger, 2010). Sebagian besar orang dewasa pernah mengalami NPB dan merupakan salah satu keluhan nyeri yang sering dijumpai di masyarakat. Angka kejadian nyeri punggung bawah diperkirakan $60 \%-85 \%$ di seluruh masyarakat dunia (Elders dan Burdoff, 2003).

Pertahunnya prevalensi nyeri punggung bawah terus meningkat dan puncaknya antara usia 35 hingga 55 tahun ( WHO, 2003). Berdasarkan Copcord Indonesia (Community Oriented Program for Controle of Rhematic Disease) prevalensi nyeri punggung bawah 18,2\% pada laki-laki dan 13,6\% pada wanita (Wirawan, 2004). Hasil Survei menyatakan $11 \%$ pasien NPB menjadi cacat, sedangkan angka kekambuhan mencapai 30\% sehingga mengakibatkan gangguan dalam (Marpaung dan Sjah, 2006). Data poliklinik RSUP Sanglah menyatakan sebanyak 249 pasien NPB melakukan rawat jalan pada tahun 2010 (RSUP Sanglah Denpasar, 2010). Data tersebut menunjukkan bahwa penanganan NPB belum memuaskan.

Pendekatan fisioterapi yang dapat dipilih untuk kasus NPB adalah short wave diathermy (SWD), Transcutaneus Electical Nerve Stimulation(TENS) dan terapi latihan diantaranya Core Stability Excercise, William's Flexion Excercise, Mc Kenzie Exercise, Back shcool exercise dan masih banyak lagi metode latihan yang baik untuk permasalahan NPB. Penanganan fisioterapi pada NPB masih menitik beratkan pada nyeri yang dirasakan, sedangkan pendekatan untuk 
meningkatkan aktifitas fungsional belum didapatkan modalitas yang tepat. Penanganan yang umum dilakukan oleh seorang fisioterapi di klinik atau rumah sakit adalah dengan pemberian short wave diathermy (SWD).

Core stabiliy exercise (CSE) adalah sebuah latihan yang mengaktifasi otot core yang berfungsi sebagai pengontrol postur tubuh (Brandon dan Raphael, 2009). Otot core sangat penting dalam menjaga postural tubuh, sehingga kekuatan dan daya tahan core muscle diperlukan untuk mencegah terjadinya cedera pada punggung bawah serta dalam upaya meningkatkan aktifitas fungsional pasien.

Berdasarkan latar belakang masalah di atas, maka penelitian ini dilakukan untuk mengetahui apakah pemberian Short Wave Diathermy dan Core Stability Exercise dapat meningkatkan kemampuan fungsional pada pasien nyeri punggung bawah miogenik.

Nyeri punggung bawah miogenik adalah nyeri pada punggung bawah yang disebabkan oleh gangguan pada unsur tendomusculer tanpa disertai dengan gangguan neurologis antara vertebra torakal 12 sampai dengan bagian bawah pinggul dan anus (Paliyama, 2003). NPB miogenik berkaitan dengan gangguan otot, tendon, dan ligamen yang berada di punggung bawah yang diakibatkan aktifitas sehari-hari yang berlebih, seperti duduk lama, berdiri lama atau mengangkat beban berat dengan cara yang salah, dimana nyeri bersifat tumpul dan tidak menjalar ke tungkai (Magee, 2013).

SWD merupakan modalitas panas melalui aplikasi arus listrik radio frekuensi tinggi dengan frekuensi 27,12 $\mathrm{MHz}$ dan panjang gelombang $11,06 \mathrm{~nm}$ (Klein, 2006). Perbedaan struktur jaringan tubuh menyebabkan efek fisiologis yang dihasilkan $S W D$ akan berbeda untuk tiap jaringan. Jaringan ikat akan mengalami peningkatan elastisitas 5-10 kali lebih besar akibat turunnya viskositas matriks jaringan. Selain meningkatkan elastisitas otot, SWD juga dapat menurunkan tonus otot melalui normalisasi nosisensorik. Jaringan saraf akan mengalami peningkatan elastisitas pembungkus jaringan saraf dan ambang rangsang (thresshold). Efek fisiologis tersebut akan memunculkan efek terapeutik yaitu peningkatan proses reparasi jaringan secara fisiologis, penurunan nyeri, normalisasi tonus otot dan perbaikan sistem metabolisme (Sugijanto, 2006).

Menurut Kibler et al (2006), Core stability didefinisikan kemampuan untuk mengontrol posisi dan gerakan bagian atas panggul dan kaki untuk memungkinkan produksi yang optimal saat melakukan transfer dan kontrol gerakan ke bagian tubuh bawah pada saat melakukan aktifitas. Core stability exercise didefinisikan sebagai latihan untuk meningkatkan kemampuan neuromuscular dalam mengontrol dan melindungi tulang belakang dari cedera. Latihan ini ditujukan untuk meningkatkan kontrol dari pada lumbopelvic. Peningkatan lumbopelvic ini dapat dilakukan melalui dua cara, yaitu: (1) meningkatkan koordinasi dan kontrol dari otot-otot lumbopelvic, (2) meningkatkan kekuatan otot-otot lumbopelvic ( Lawrence, 2013).

\section{METODE}

\section{Rancangan Penelitian}

Rancangan penelitian ini bersifat pre eksperimental dengan rancangan pretest and posttest group design, (Pocock, 2008).

\section{Populasi}

Populasi dalam penelitian ini adalah pasien nyeri punggung bawah miogenik yang datang ke tempat praktek swasta fisioterapi di denpasar

\section{Sampel}

Teknik pengambilan sampel dilakukan dengan teknik purpossive sampling dengan menggunakan pemeriksaan fisioterapi dan sesuai dengan kriteria yang telah ditetapkan peneliti. Kriterian pengambilan sampel :

\section{Kriteria inklusi meliputi:}

a. Pasien dengan nyeri punggung bawah miogenik yang didiagnosa oleh dokter

b. Usia antara 25-50 tahun

c. Nyeri punggung bawah telah melewati masa akut, yaitu minimal lebih dari 10 hari

d. Penderita wanita tidak sedang hamil

e. Tidak adanya kelainan neurologis

f. Dapat berkomunikasi dengan baik

g. Kooperatif dan bersedia mengikuti program penelitian.

\section{Kriteria eksklusi meliputi:}

a. Mempunyai gangguan kardio (jantung)

b. Ada hnp

c. Ada gangguan syaraf paraesthesi

d. Tumor ganas.

\section{Kriteria drop out jika :}

a. Tidak melakukan terapi 2 kali berturutturut atau tidak berturut-turut

b. Penderita selama penelitian tidak teratur mengikuti prosedur penelitian

c. Pasien meninggal dunia.

d. Gangguan bladder dan bowel

\section{Analisis Data}

Analisis data yang digunakan dalam penelitian menggunakan bantuan SPSS. Data dari kelompok akan di uji normalitasnya dengan Shapiro Wilk-Test dengan tingkat kemaknaan 0,05.Uji pengaruh menggunakan Wilcoxon test dengan tingkat kemaknaan 0,05. 


\section{HASIL PENELITIAN DAN PEMBAHASAN}

Pengambilan data penelitian telah dilaksanakan di klinik daerah Denpasar. Subjek Distribusi Uji normalitas penelitian berjumlah 14 orang, dan mendapatkan terapi SWD ditambah Core stability dengan frekuensi 3 kali perminggu selama 2 minggu.

Tabel 1 Hasil uji normalitas dan homogenitas skor ODI

\begin{tabular}{ll}
\hline Skor ODI & $\begin{array}{l}\text { Saphiro Wilk test } \\
(\mathrm{p})\end{array}$ \\
\hline Sebelum perlakuan & 0,19 \\
Setelah perlakuan & 0,00 \\
\hline
\end{tabular}

Hasil uji normalitas, didapatkan skor penurunan ODI sebelum pelatihan didapatkan nilai $\mathrm{p}=0,19$ (berdistribusi normal), dan setelah pelatihan didapatkan nilai $\mathrm{p}=0,00$ (berdistribusi tidak normal) sehingga pengujian selanjutnya dengan uji non parametrik.

\section{Uji Perbedaan Penurunan Skor ODI}

Tabel 2 Uji hipotesis penurunan skor ODI sebelum dan sesudah pelatihan

\begin{tabular}{lccll}
\hline Kel & $\mathrm{N}$ & Median \pm SB & \multicolumn{2}{c}{ wilcoxon rank test } \\
\hline & & & $\mathrm{z}$ & $\mathrm{p}$ \\
\hline $\begin{array}{l}\text { Sebelum } \\
\text { pelatihan }\end{array}$ & 14 & $42 \pm 12,34$ & & \\
\begin{tabular}{l} 
Setelah pelatihan \\
\hline
\end{tabular} & 14 & $8 \pm 12,26$ & $-3,30$ & 0,00 \\
\hline
\end{tabular}

Berdasarkan analisis data skor ODI sebelum dan setelah pelatihan dengan menggunakan uji Wilcoxon match pair test tertera pada tabel 2, didapatkan nilai tengah sebelum pelatihan $42 \pm 12,34$ dan setelah pelatihan $8 \pm 12,26$ dengan $p=0,00 \quad(p<0,05), \quad$ sehingga terjadi penurunan skor ODI . Dengan hasil di atas dapat disimpulkan bahwa pemberian pelatihan $S W D$ dan Core Stability Exercise dapat meningkatkan aktivitas fungsional pada pasien NPB miogenik.

SWD merupakan terapi thermal yang efektif diberikan sebelum pelatihan. Efek fisiologis dari $S W D$ akan mengakibatkan jaringan ikat mengalami peningkatan elastisitas akibat turunnya viskositas matriks jaringan karena homeostasis lokal sehingga jaringan akan mudah digerakkan dan kelenturannya bertambah. Hal tersebut mengakibatkan waving efek akan mudah didapatkan dan reseptor saraf $\mathrm{A} \delta$ dan $\mathrm{C}$ yang terjebak akibat tekanan jaringan fibrous akan terbebas sehingga nyeri berkurang (Sugijanto, 2006). Kondisi seperti itu sangat membantu program pelatihan Core Stability Exercise yang diberikan.

Core Stability Exercise mengakibatkan batang tubuh menjadi stabil karena mampu mengontrol posisi dan gerakan (Brandon dan Raphael, 2009). Target utama latihan ini adalah otot yang terletak pada bagian dalam perut, dimana otot ini memiliki terkoneksi dengan tulang belakang, panggul, dan bahu. CSE bermanfaat untuk stabilisasi punggung bawah, baik pada saat tidak bergerak maupun saat bergerak, serta mencegah terjadinya cedera (pada punggung dan ekstremitas bawah) terutama dalam aktivitas fungsional. Ketika core muscle lemah atau tidak ada keseimbangan (imbalance muscle) akan mengakibatkan rasa sakit di daerah punggung bawah. CSE akan meningkatkan keseimbangan otot abdominal dan paravertebrae karena terjadi koaktivitas otot dalam dari trunk bawah yang dapat mengontrol selama terjadinya pergerakan perpindahan berat badan, aktivitas fungsional dari ekstremitas seperti meraih dan melangkah (Panjabi, 2013).

CSE merupakan latihan yang efektif untuk mencegah, mengobati NPB dan cereda ekstremitas bawah terutama dalam meningkatkan aktifitas fungsional (Hodges and Richardson, 1999).

\section{SIMPULAN}

Short wave diathermy dan core stability exercise meningkatkan kemampuan fungsional pada pasien nyeri punggung bawah miogenik.

\section{SARAN}

Metode latihan core stability exercise perlu ditambahkan pada terapi Short Wave Diathermy, mengingat bahwa peningkatan aktivitas fungsional pada pasien NPB miogenik lebih besar setelah diberikan latihan core stability exercise. 


\section{DAFTAR PUSTAKA}

Elders, L.A.M. and Burdoff, A. (2003). Prevalence incidence and recurrence of low back pain in Scaffolders during a three year follow up study. In : Elders LAM, ed work related musculoskeletal disorder in Scaffolders. Rotterdam, hal. 19-30

Marpaung, B., Sjah M. (2006). Penatalaksanaan nyeri pinggang kronis. dalam, Setiyohadi, Kasjmir, editor. Temu Ilmiah Reumatologi 2006, Jakarta, hal. 14 -17.

Brandon dan Raphael. (2009). Core stability training and Core stability program http://www.sportinjurybulletin.com/archive/ core-stability.html.

Magee, D.J. (2013). Orthopaedics condition and treatment . sixth edition, WB Saunders Company, Philadelpia, hal. 209-230.

Klein, M.J. (2006). Deep Heat. Available. http://www.emedicine.com/pmr/topic203.ht m.

Sugijanto. (2006). Perbedaan Pengaruh Pemberian Short Wave Diathermy (SWD) dan Contract
Relax And Stretching Dengan Short Wave Diathermy dan Transvers Friction Terhadap Pengurangan Nyeri Pada Sindroma Nyeri Miofasial Otot Levator Skapula. Fisioterapi Indonesia, 6 (1). Hal. 46-66.

Kibler, B.W., Press, J., and Sciascia, A. (2006). The Role of Core Stability in Athletic Function. Sports Medicine, 36 (3), 189-198.

Pocock, J. Stuart. (2008). Clinical Trials: A Practical Approach. Chichester: John Wiley \& Sons.p. The Society of Obstetricians and Ginaecologist of Canada.

Hodges, P.W, and Richardson, C.A. (1999). Altered trunk muscle recruitment in people with low back pain with upper limb movement at different speeds. Archives of Physical medicine ang rehabilitation, hal 1005-1012.

Panjabi, M.M. 2013. The Stabilizing system of the Spine. Part II. Neutral Zone and Instability Hypothesis. Journal of Spinal Disorder, hal 390-396 